\title{
ARCHEOLOGIJOS MOKSLO VAIDMUO LIETUVOS KARO ISTORIJOS TYRIMUOSE
}

\author{
Manvydas Vitkūnas \\ (Vilniaus universitetas)
}

Archeologija, būdama savarankiška istorijos mokslo šaka, tiriančia seniausiają visuomenės istoriją ir jos raidos désningumus, yra viena pagrindinių mokslo disciplinų, teikiančių informaciją apie neatsiejamą visų civilizacijų ir kultūrų raidos dalị - karybą.

Pagrindinis archeologinių tyrimų objektas - materialinès ir dvasinès kultūros pėdsakai. Karas, kaip prievartos mechanizmas, visais laikais rèmèsi materialiniais ištekliais, būtinais kario veiksmams aprūpinti, ir religiniais bei ideologiniais ịsitikinimais, palaikančiais kovos dvasią. Karinio aktyvumo praeityje pėdsakai labai dažnai aptinkami archeologinių tyrinejimų metu net ir tada, kai pagrindiniai tyrinejjimų tikslai yra nesusiję su karybos istorijos tyrimais.

Archeologiniai mokslinių tyrimų metodai karybos raidai pažinti yra svarbūs tiek kaip vienintelis būdas atsekti seniausius karinio aktyvumo pėdsakus iš tų laikų, kai dar nebuvo arba neišliko rašytinių šaltinių, tiek kaip paraleliniai (greta rašytinių šaltinių analizès) viduramžių epochos tyrimai, tiek kaip pagalbiniai tyrimai, tyrinejantys naujujų laikų karybos pėdsakus.

Remiantis archeologinių tyrinėjimų medžiaga, galima pažinti praeities žmonių ginkluotę ir fortifikaciją, iš dalies - karinę organizaciją, o kartais - ir karinių veiksmų detales.

Šiame straipsnyje pasistengsime trumpai apžvelgti pagrindines esamas ir galimas archeologinių tyrinejjimų kryptis, susijusias su Lietuvos karybos istorijos pažinimu. Straipsnio apimtis neleidžia plačiai apžvelgti visų atliktų darbų, todèl apsiribosime tik pagrindiniais.

Archeologiškai atsekamus žmonių karinès veiklos pėdsakus galima suskirstyti ị kelias pagrindines grupes, iš kurių akivaizdžiausios yra dvi: ginkluote ir jos elementai, bei fortifikaciniai įrenginiai ir jų liekanos. Be to, karybos istorijos tyrimams yra svarbūs laidojimo paminklai, kuriuose dažnai aptinkami karių palaidojimai su jų turèta ginkluote ir apsaugos elementais, taip pat kovų metu žuvusių žmonių (nebūtinai karių) palaikai, kartais - žirgų kapai, taip pat senųjų gyvenviečių, dažniausiai ne kartą patyrusių karinius antpuolius, pédsakai. Amatų (ypač metalų gavybos, kalvystès, juvelyrikos) tyrimai lei- 
džia pažinti karinėms reikmėms (visų pirma ginklų gamybai) naudotų technologijų raidą. Taip pat svarbi osteologinès medžiagos, randamos senuosiuose kapinynuose, o kartais - ir gyvenvietèse bei gynybiniuose įtvirtinimuose, analize, leidžianti daugiau sužinoti apie praeities žmonių kovų metu patirtus sužalojimus, atskleisti daugiau dramatišku praeities kovų puslapių.

Senosios karybos pedsakais domejosi jau pirmieji Lietuvos archeologai ir istorikai, tačiau specialios publikacijos pasirode tik tarpukario metais ${ }^{1}$. Šiuo laikotarpiu archeologiniuose tyrinejimuose aktyviai dalyvavo kai kurie Lietuvos kariuomenès karininkai - Petras Tarasenka, Vladas Nagevičius. Pastarasis karininkas ir archeologas atliko vienus garsiausių tarpukario Lietuvoje Apuolès ir Impilties piliakalnių tyrinejimus. V. Nagevičiaus nuopelnai Lietuvos archeologijai išties yra dideli. „V. Nagevičius pirmasis nepriklausomoje Lietuvoje pradèjo archeologinius tyrinèjimus, juos vykdydamas aukštu metodiniu lygiu. Kasinejimuose jis pirmasis panaudojo tokias naujoves kaip aerofotografija, filmavimas, profesionalius dailininkus, fotografus, kitu sričių konsultantus. V. Nagevičius Lietuvos archeologijos laimejjimus pradèjo pristatinèti prestižiniuose užsienio archeologų kongresuose, pagaliau jis padejo pagrindus išsamiai lietuviškai archeologinès medžiagos publikacijai, iskaitant ir naujų archeologinių terminų panaudojimą“" 2 V. Nagevičiaus iniciatyva Kaune 1921 m. įkurtas Vytauto Didžiojo karo muziejus, ilgainiui išrutuliojęs plačią archeologinę veiklą.

Visi Lietuvos proistorès ir viduramžių laikotarpiai turi pakankamai archeologines ${ }^{3}$ medžiagos, svarbios karybos tyrimams, tačiau atliktų tyrimų lygmuo yra labai skirtingas.

Bene menkiausiai karybos istorijos atžvilgiu ištirtas ilgas, dešimtị tūkstančių metų trukęs laikotarpis nuo pirmụjų žmonių pasirodymo dabartineje Lietuvos teritorijoje iki ankstyvojo geležies amžiaus pabaigos. Sukaupta pakankamai nemažai medžiagos apie to meto

\footnotetext{
${ }^{1}$ Tarasenka P. Priešistoriniai lietuvių karo žygiai // Medžiaga kariškai Lietuvos istorijai. K., 1928. p. 7-27; Tarasenka P. Piliakalniai // Medžiaga kariškai Lietuvos istorijai. K., 1928. p. 102-120; Tarasenka P. Senovès ir dabarties Lietuvos kariai // Karys. K., 1928, Nr. 20, p. 348351; Tarasenka P. Žemaičių gynimasis nuo kryžiuočių // Medžiaga kariškai Lietuvos istorijai. K., 1928. p. 91-102; Štuopis P. Senovès aisčių sauga // Trimitas. K., 1933, Nr. 47, p. 926-928, Nr. 48, p. 949-950, Nr. 49, p. 966-967; Sideravičius K. Senovès lietuvių artilerija. / K. Sidera // Karys. 1934, Nr. 3, p. 51; Šeštakauskas P. Šarvai: šarvų, pentinų ir skydų trumpa istorine apžvalga. K., 1936.

${ }^{2}$ Kulikauskas P., Zabiela G. Lietuvos archeologijos istorija (iki 1945 m.). V., 1999, p. 195.

${ }^{3}$ Rimantiene R. Akmens amžius Lietuvoje. V., 1996; Grigalavičienė E. Žalvario ir ankstyvasis geležies amžius Lietuvoje. V., 1995.
} 
medžioklès ịrankius ir ginkluotę, kai kuriuose apibendrinamojo pobūdžio darbuose gana nemažai vietos skiriama ginklams, o kalbant apie bronzos ir ankstyvaji geležies amžių - ir įtvirtinimų statybos pradžiai, tačiau iki šiol nèra specializuotų darbų, o pavieniai straipsniai yra gana kuklūs ${ }^{4}$. O darbų čia pakankamai daug - tai ir detalesné medžioklès įrankių ir ginklų tipologija, ir bandymai ieškoti ribos, kai greta medžioklès įrankių, tinkamų tiek medžioklei, tiek kovai su žmonèmis, atsiranda ginklai. Toli gražu nepakankamai gerai atskleista indoeuropiečių įtaka militarinio prado raidai besiformuojančiame baltų etnose (šia tema daugiausia domèjosi Marija Gimbutienè), žirgų naudojimo pradžia ir to įtaka karybos papročių kaitai. Taigi apibendrinant galima pasakyti, kad laikotarpis iki Kristaus gimimo yra „pilkiausia zona“ Lietuvos karybos istorijos pažinime, nors kaip tik šio laikotarpio archeologiniuose paminkluose yra aptinkami seniausio žmonių karinio aktyvumo pėdsakai.

Kur kas geriau karybos istorijos atžvilgiu yra ištirtas pirmojo tūkstm. po Kristaus gimimo laikotarpis ir antrojo tūkstm. pradžia - senasis, vidurinysis ir vèlyvasis geležies amžiai. Šio laikotarpio ginkluotės tipologija ir chronologija yra geriausiai išnagrinèta, lyginant tiek su ikikristiniu laikotarpiu, tiek su viduramžiais. Daugiausia tai - Vytauto Kazakevičiaus nuopelnas ${ }^{5}$. Myko${ }^{4}$ Grigalavičiené E. I tūkstantmečio pr. m. e. Lietuvos piliakalnių kaulo dirbiniai (2. Medžioklès ir žvejybos įrankiai, ginklai) // Lietuvos TSR mokslų akademijos darbai. A serija (toliau MADA), T. 1 (54). V., 1976, p. 51-56; Juodagalvis V. Akmens amžiaus ginklai Lietuvoje // Tarptautinès mokslinès-praktinès konferencijos „Lietuvos karybos istorijos klausimai medžiaga. Kaunas, 1992, p. 3.

${ }^{5}$ Kazakevičius V. Ietigaliai Lietuvoje V-VIII a. (1. İtveriamieji) // MADA, T. 4. V., 1978, p. $37-$ 45; Kazakevičius V. V-IX a. pradžios kalavijai Lietuvoje // Jaunujų istorikų darbai, Kn. 2. V., 1978, p. 14-23; Kazakevičius V. Ietigaliai Lietuvoje V-VIII a. (2. Imoviniai) // MADA, T. 2. V., 1979, p. 63-65; Kazakevičius V. Vienašmenių kalavijų atsiradimas ir raida Lietuvoje // Lietuvos archeologija, T. 2. V., 1981, p. 43-58; Kazakevičius V. M. e. I tūkstantmečio strẻlių antgaliai Lietuvoje // Jaunujų istorikų darbai. Kn. 4. V., 1982, p. 91-93; Kazakevičius V. IX-XII a. baltų kalavijai. V., 1996; Kazakevičius V. Geležies amžiaus baltų genčių ginkluotė: Habilitacinis darbas. Humanitariniai mokslai, 05H Istorija. V., 1998; Kazakevičius V. Iš vẻlyvojo geležies amžiaus baltų ginklų istorijos (Kalavijų makštų apkalai) // Lietuvos archeologija, T. 15, V., 1998, p. $287-$ 332; Kazakevičius V. Some debatable questions Concerning the Armament of the Viking Period in Lithuania // Fasciculi archeologiae historicae (Lódz). 1994, sąs. 7, p. 37-44; Kazakevičius V. Topory bojowe typu M: Chronologia I pochodzenia na ziemiach Baltow // Słowianszczyzna w Europie sredniowiecznej. Wrocław, 1996, s. 233-241; Kazakevičius V. On one type of Baltic sword of the Wiking Period // Archaeologia Baltica, T. 2, 1997, p. 117-132; Казакявичюс В. Боевые топоры на територии Литвы и Белоруссии в I тысячелетии н. э. // Древности Белоруссии и Литвы. Минск, 1982, с. 39-42; Казакявичюс В. Развитие вооружения жсттелей Литвы в I тысячелетии н. э. // Археология и история Пскова и Псковской земли. Псков, 1986, с. 53-54; Казакявичюс В. Оружие балтских племен II-VIII вв. на територии Литвы. В., 1988; Казакявичюс В. Редкая форма наконечников копий на територии Литвы // Древности Белоруссии и Литвы. Минск, 1988, с. 79-88. 
lo Michelberto ${ }^{6}$ ir Adolfo Tautavičiaus ${ }^{7}$ monografijose, kuriose apibendrinami atskirų geležies amžiaus periodų tyrinejjimų duomenys, ginklams skirti atskiri skyriai. A. Tautavičius, didesnę mokslinès veiklos dali paskyręs viduriniojo geležies amžiaus problematikai, yra tyrinejjęs labai svarbų karybos istorijai Taurapilio „kunigaikščio kapą“8 . A. Tautavičius taip pat ịneše didelị indèli i i pilių tyrimus, tyrinejo Vilniaus Žemutinę, Trakų Pusiasalio, Klaipedos pilis, Veliuonos piliavietę. Kalbant apie geležies amžiaus ginkluotès tyrimus, būtina paminèti Reginos Volkaitès-Kulikauskienès darbus'. Taip pat svarbūs senosios ginkluotès pažinimui yra metalų gavybos tyrinètojų darbai Jono Stankaus straipsniai apie geležies gavybą ir kalvystę senovès Lietuvoje, ịskaitant ginklu technologinius tyrimus ${ }^{10}$, latviu archeologo Aleksio Anteino darbai apie dirbinius iš Damasko plieno ${ }^{11}$. Derétų paminèti ir Juozo Antanavičiaus straipsnius apie žirgų aprangos elementus ${ }^{12}$, Arvydo Malonaičio straipsnius apie siauraašmenius pentinius kirvius Lietuvoje ${ }^{13}$, Valdemaro Šimèno straipsnius apie kovos

\footnotetext{
${ }^{6}$ Michelbertas M. Senasis geležies amžius Lietuvoje. V., 1986.

${ }^{7}$ Tautavičius A. Vidurinis geležies amžius Lietuvoje (V-IX a.). V., 1996.

${ }^{8}$ Tautavičius A. Taurapilio „kunigaikščio“ kapas // Lietuvos archeologija. T. 2. V., 1981. p. 18-43.

${ }^{9}$ Volkaitė-Kulikauskienė R. IX-XIIa. kalavijai Lietuvoje // Iš lietuvių kultūros istorijos. T. 4. V., 1964, p. 197-226; Volkaite-Kulikauskienè R. Kovos kirviai Lietuvoje ankstyvojo feodalizmo laikotarpiu // MADA, T. 1. V., 1964, p. 101-114; Volkaité-Kulikauskienè R. Ankstyviausiu šalmų Lietuvoje klausimu // MADA, T. 2. V., 1965, p. 59-71; Volkaitė-Kulikauskienè R. Lietuviai IX-XII a. V., 1970; Volkaitė-Kulikauskienė R. Lietuvio kario žirgas. V., 1971; Volkaitė-Kulikauskienė R. Ginklai // Lietuvių materialinė kultūra IX-XII a. T. 2. V., 1981, p. 6-47; Volkaitė-Kulikauskienė R. Lietuva valstybès priešaušriu. V., 2001; ВолкайтеКуликаускене Р. По вопросу самых древнейших шлемов в Литве // Liber Iosepho Kostrzewski octogenario a veneratoribus dicatus. Wroclaw, 1968, p. 475-483.

${ }^{10}$ Stankus J. Kalavijų ir ietigalių technologija Lietuvoje IX-XIII amžiais // MADA, T. 2. V., 1979, p. 113-130.

${ }^{11}$ Anteins A. Im Ostbaltikum gefundene Schwerter mit damaszierten Klingen // Waffen und Kostumkunde. Munchen, Berlin, 1966, s. 111-125; Антейн А. Наконечники копии из сварочной узорчатой (Дамасской) стали в древней Прибалтике // Советская археология. № 4. Москва, 1963 с. 167-178; Антейн А. Древнее оружие из Дамасской стали в Литве // Материалы VI-ой конференции по истории науки в Прибалтике. B., 1965 c. 78-80; Антейн А. Наконечники копии с посеребреными втулками в древней Прибалтике и исследование дамаскирования их перев // Studia archeologiczne (Wroclaw), T. 1, 1967, p. 289-305; Антейн А. Дамасская сталь в странах Балтийского моря. Рига, 1973.

${ }^{12}$ Antanavičius J. Geležiniai žirgo aprangos dirbiniai // Kraštotyra. V., 1975, p. 188-194; Antanavičius J. X-XIII a. balno kilpos Lietuvoje // MADA, T. 1. V., 1976, p. 69-81.

${ }^{13}$ Malonaitis A. Siauraašmeniai pentiniai kirviai Lietuvoje (tyrinejimų metmenys) // Istorija. T. 35, V., 1997, p. 48-77; Malonaitis A. Ornamentuotieji siauraašmeniai pentiniai kirviai Lietuvoje // Istorija. T. 38, V., 1998, p. 3-11.
} 
peilius-durklus ${ }^{14}$ ir daugelị kitų. Albinas Kuncevičius yra paskelbęs apžvalginio pobūdžio straipsnị apie baltų karybą nuo seniausių laikų iki Lietuvos valstybès susidarymo ${ }^{15}$. Tarp įdomesnių naujausių publikacijų paminètinas Eugenijaus Butèno straipsnis, kuriame publikuojama dalis Kurklių Šilo pilkapyno tyrinèjimo duomenų, aptariami šiame pilkapyne ir kitose Lietuvos vietose rasti raitelių innagių - rimbų išlikusios dalys - botkočiai ${ }^{16}$. Vienaip ar kitaip didesnei daliai ginkluotès tipų iš I-XII a. yra skirti atskiri apibendrinamojo pobūdžio straipsniai ir knygos, nors spragų dar yra. Be to, labai daug duomenų apie visų priešistorès ir viduramžių laikotarpių ginklus, žirgų aprangą, raiteliu įnagius pateikiama straipsniuose ir monografijose, skirtose atskirų laidojimo paminklų, piliakalnių, pilių tyrimams.

Archeologinių tyrinèjimų duomenys leidžia pažinti ne tik ginkluotės tipus ir gynybinių itvirtinimų konstrukcijas. Keletas publikacijų yra skirta tokiam svarbiam ir dar mažai tyrinètam karybos istorijos barui, kaip kariaunos atsiradimas ir raida baltu gentyse. Čia derètụ paminèti Laimos Vaitkunskienės straipsnius, skirtus kariaunos atsiradimui Lietuvos teritorijoje ${ }^{17}$, ir maskviečio archeologo Vladimiro Kulakovo straipsnius apie prūsų kariauną. Pastarasis archeologas yra skyręs gana daug dèmesio prūsų genčiu karybai ${ }^{18}$. Tenka pastebė-

${ }^{14}$ Šimėnas V. Smailieji kovos peiliai - durklai baltų kraštuose I m. e. tūkstantmečio viduryje // Vidurio Lietuvos archeologija: Etnokultūriniai ryšiai. V., 1996, p. 27-71; Шименас В. Боевые ножи - кинжалы в Балтийском ареале в V-VI вв. // Археология и история Пскова и Псковской земли. Псков, 1992, с. 96-100.

${ }^{15}$ Kuncevičius A. Baltu karyba // Istorija. T. 50. V., 2001, p. 66-76.

${ }^{16}$ Butėnas E. Kario raitelio kapas iš Kurklių šilo pilkapyno // Lietuvos archeologija. T. 21. V., 2001, p. 227-234.

${ }^{17}$ Vaitkunskiene L. The formation of a varrior elite during the Middle Iron Age in Lithuania // Archaeologia Baltica. V., 1995, p. 94-106; Вайткунскене Л. К вопросу о начале дружины в Литве // Задачи советской археологии в свете решений XXVII сезда КПСС: Тезисы докладов (Суздаль, 1987 г.). М., 1987, с. 56-57.

${ }^{18}$ Кулаков В.И. Начало дружины пруссов // Всесоюзная конференция по изучению истории, археологии, экономики, литературы и языка скандинавских стран и Финляндии. Тезисы докладов. Москва, 1986, с. 188-190; Кулаков В.И. Дружинные элементы в могильниках пруссов VII - начале XI в.// Археологческие памятники Европейской части РСФСР: Погребальные памятники. Москва, 1988, с. 119-145; Кулаков В.И. Знамена дружин балтского региона // Советская археология. Москва, 1989, № 4, с. 61-70; Кулаков B. И. Погребения военчалников прусских дружин // Краткие сообщения Института археологии Академии наук СССР. Москва - Ленинград, 1989, вып. 198, с. 35-44; Кулаков В. И. Конское снаряжение в X-ХI вв. (проблемы относительной хронологии деталей оголовия) // Lietuvos archeologija. T. 9. V., 1992, p. 137-144; Кулаков В.И. Культовое оружие балтов и славян X-ХII вв. // Slavica Antiqa. Poznan. 1992-1993 Т. 33, p. 115-129. 
ti, kad kaimyninėse šalyse yra sukaupta labai gausi tyrinèjimų medžiaga, nemažai pavienių darbų, skirtų ten gyvenusių baltų genčių karybai, tačiau Lietuvos archeologai iki šiol tuo beveik visiškai nesidomejjo. Bandymų aptarti su karybos istorijos raida susijusius klausimus plataus baltu gyvento regiono mastu kol kas beveik nèra. Vienintelis rimtesnis bandymas - V. Kazakevičiaus knyga apie baltų kalavijus IX-XIII a., kurią rengiant pasinaudota Lietuvos, Latvijos, Karaliaučiaus krašto, dalies vakarų Baltarusijos ir šiaurès vakarų Lenkijos archeologiniu tyrinejimų duomenimis ${ }^{19}$.

Archeologiškai labai sunkiai atsekamas karinès veiklos momentas yra patys karo veiksmai. Visgi analitiškai žvelgiant į gausią tyrinejjimų medžiagą galima atsekti labai ịdomių praeities momentų. Turime omenyje itin įdomų ir vertingą Aleksiejaus Luchtano straipsnį ${ }^{20}, 1997$ $\mathrm{m}$. publikuotą viename iš Baltarusijos mokslinių leidinių. Remdamasis vien archeologiniais duomenimis (nes kitokiu paprasčiausiai nėra), autorius pakankamai argumentuotai grindžia nuomonę, jog $\mathrm{V}$ a. i Lietuvos teritoriją įsiveržè tam tikros stepių klajoklių (veikiausiai hunų) pajègos, nurodo jų pultas vietoves ir apytiksli žygio maršrutą.

Kalbant apie viduramžių laikotarpio archeologinius tyrinèjimus, krenta ị akis du pagrindiniai momentai - gana neblogai ištirta fortifikacija ir pakankamai prastai ištirta ginkluote. Apie viduramžiu ginkluotę beveik neturime apibendrinamojo pobūdžio darbų. Išskirtiniai yra Gintauto Rackevičiaus darbai, skirti kovų su kryžiuočiais laikų arbaletui Lietuvoje ${ }^{21}$. Tuo tarpu viduramžių Lietuvos gynybiniuose įtvirtinimuose ir ypač kapinynuose rasta dešimtys kalavijų, šimtai kirvių ir ietigalių. Gana daug duomenų apie viduramžių laikotarpio ginklus Lietuvoje pateikiama publikacijose, skirtose apžvelgti atskiru archeologijos paminklų (ypač kapinynų) tyrinejjimų rezultatus. Kaimyniniuose kraštuose panašūs radiniai seniai apibendrinti, tipologizuoti. Pas mus šiuo klausimu padaryta kur kas mažiau nei Baltarusijoje, jau nekalbant apie Lenkiją. Beje, viduramžių ginkluotès tyrimai - ne vien archeologų, bet ir istoriku kompetencija, juolab ${ }^{19}$ Kazakevičius V. IX-XII a. baltų kalavijai. V., 1996.

${ }^{20}$ Лухтан А. Война V века в Литве // Гістарычна - археалагічны зборнік. Т.11. Беларусь у сістэме Еурапейскіх културных сувязяу. Мінск, 1997, с. 15-20.

${ }^{21}$ Rackevičius G. XV a. pradžios arbaleto ir lanko strèlių antgaliai Vilniaus Žemutinèje pilyje // Baltų archeologija. 1996 Nr. 1 (18), p. 23-25; Rackevičius G. Arbaletas, jo modifikacijos ir prototipai Lietuvoje XIII-XVI a. Daktaro disertacijos santrauka. V., 2000; Rackevičius G. Arbaletas Lietuvos pilių tyrimų duomenimis // Lietuvos pilių archeologija. Klaipėda, 2001, p. 231-250; Rackevičius G. Arbaleto strèlès laikikliai iš Vilniaus pilies // Lietuvos archeologija. T. 21. V., 2001, p. 375-382. 
turime ne tik archeologinių radinių, bet ir rašytinių šaltinių paliudijimų, ikonografinès medžiagos. Pastaraisiais metais Vilniaus universitete keli studentai buvo pasirinkę viduramžių ginkluotės tyrimus. Deja, ši tema jiems pasirodè ne mažiau sudètinga, nei romantiška. Viduramžių ginklai dar laukia savo tyrinėtojų.

Pakankamai neblogai tiek Lietuvoje, tiek kaimyniniuose kraštuose yra ištirti gynybiniai ịtvirtinimai, ypač priklausantys viduramžių epochai ir naujiesiems amžiams. Tai piliakalnių, juose buvusių medinių slèptuvių, pilių, taip pat mūrinių pilių ir kitų gynybinių įtvirtinimų tyrimai. Yra publikuota šimtai straipsnių medinių pilių tyrimų tematika, šiems klausimams skirtos atskiros tam tikrų laikotarpių ir regionų tyrinejjimų duomenis apibendrinančių monografijų dalys, todẻl paminèsime tik pagrindinius darbus. Piliakalniais, gynybiniais itvirtinimais, piliakalnių registracija daugiau ar mažiau doméjosi jau XIX a. ir XX a. pirmosios pusès archeologai, tarp jų - Vandalinas Šukevičius, Tadas Daugirdas, Eduardas Volteris, Fiodoras Pokrovskis, Liudvikas Kšivickis, Petras Tarasenka, Vladas Nagevičius. Laikotarpiu nuo II pasaulinio karo iki mūsų dienų didžiausią indẻlị i cietuvos piliakalnių tyrinèjimus įnešè Pranas Kulikauskas, Regina Volkaitè-Kulikauskienè, Gintautas Zabiela, Adolfas Tautavičius, Aleksiejus Luchtanas, Algimantas Merkevičius, Elena Grigalavičiené, Jonas Stankus. Taip pat labai reikšmingi Vytauto Daugudžio darbai Lietuvos piliakalnių, senosios medinès statybos tyrimų klausimais ${ }^{22} .1995$ m. pasirodžiusioje Gintauto Zabielos knygoje ${ }^{23}$ profesionaliai ir kritiškai ịvertinta ir apibendrinta ligi tol Lietuvos archeologų sukaupta labai gausi medžiaga seniai nuo žemès paviršiaus išnykusių medinių pilių istorijos klausimais. G. Zabiela yra paskelbęs ir daugiau reikšmingų straipsnių, skirtų vẻlyvujų piliakalnių tyrinejjimams ${ }^{24}$. Taip pat atskirai reikètų paminėti unikaliam XII-XIII a. datuojamam gynybiniam įrenginiui - Rẻkučių pylimui skirtą Algirdo Girininko ir Vido Seméno publikaciją ${ }^{25}$.

\footnotetext{
${ }^{22}$ Daugudis V. Aukštadvario piliakalnio pastatai ir įtvirtinimai // MADA, T. 1(12), V., 1962, p. 43-69; Daugudis V. Seniausieji mediniai pastatai ir irengimai Lietuvoje // MADA, T. 2(75), V., 1981, p. 61-73; Daugudis V. Senoji medinè statyba Lietuvoje V., 1986; Daugudis V. I tūkstantmečio pr. m. e. Šiaurès Žemaitijos piliakalniai (1. Būdingesnieji piliakalnių bruožai ir jų ịtvirtinimai) // MADA, T. 2(95), V., 1986, p. 31-42.

${ }^{23}$ Zabiela G. Lietuvos medinès pilys. V., 1995.

${ }^{24}$ Zabiela G. Piliakalnių likimas Lietuvos valstybės susidarymo išvakarèse // Lituanistica. T. 4 (18). V., 1991, p. 22-42; Zabiela G. Piliakalniai - slëptuvès // Lietuvos archeologija. T. 21. V., 2001, p. 399-412.

${ }^{25}$ Girininkas A., Semėnas V. XIII a. Rèkučių gynybinis įrenginys // Kultūros paminklai. T. 2. V., 1995 , p. 28-35.
} 
Taip pat labai gausi medžiaga sukaupta tyrinejjant ne tiek jau daug Lietuvoje turimų mūrinių pilių, tačiau po $1971 \mathrm{~m}$. išleistos kny-

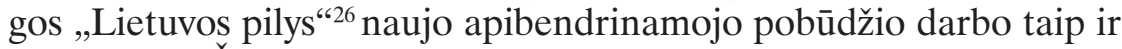
nepasirodè. Šią spragą šiek tiek užpildè $2001 \mathrm{~m}$. išleista labiau plačiajai visuomenei skirta knyga „Lietuvos gynybiniai itvirtnimai“ ${ }^{\text {“27. }}$ O per tris dešimtmečius po knygos „Lietuvos pilys“ išleidimo daugelyje ten aprašomu pilių vyko tyrinejjimai, sukaupti nauji duomenys verčia pakoreguoti nemažai minètame leidinyje pateiktų teiginių. Pačioje $2001 \mathrm{~m}$. pabaigoje Klaipėdos universiteto leidykla išleido straipsnių rinkinįi ${ }^{28}$, kuriame publikuojami archeologų, architektūros istorikų, paleoosteologų straipsniai, skirti motų tipo ịtvirtinimų, Klaipèdos, Trakų, Senųjų Trakų, Biržų, Vilniaus pilių, kai kurių pilyse aptinkamų radinių tyrimams. Norisi tikèti, kad šis leidinys ilgainiui taps tęstiniu. Lietuvoje yra pakankamai nemažai pilių archeologija užsiimančių archeologų. Be to, didžiulị indẻlị ị mūrinių pilių tyrimus yra innešę architektūros tyrinètojai, istorikai. Jų darbą keletą pastarųuu metų labai sunkino prastas tyrinèjimų finansavimas. Visgi tiek mūriniu pilių tyrinèjimai, tiek pilių restauravimo ir atstatymo procesai juda pirmyn. Piliakalnių, mūrinių pilių, kitų gynybinių įtvirtinimų tyrimams yra skirta šimtai publikacijų.

Dar viena mokslinių tyrinejimų kryptis, teikianti informacijos apie praeities karinius konfliktus, - antropologija, visu pirma paleopatologija. Šioje srityje Lietuvoje daugiausia yra nuveikę Vilniaus universiteto Medicinos fakulteto mokslininkai, visu pirma Rimantas Jankauskas ${ }^{29}$. Paleopatologija leidžia daugiau sužinoti apie praeities žmonių kovose patirtas traumas, paleodemografija - apie karinių konfliktų ịtaką tam tikroms žmonių bendruomenėms.

Šiame straipsnyje apžvelgtos tik pagrindinès ligšiolinių archeologinių tyrimų, susijusių su karybos istorija, kryptys ir problemos. Autorius nebando straipsnio praturtinti išsamia bibliografija. Adolfo Tautavičiaus sudarytoje Lietuvos archeologijos bibliografijoje ${ }^{30}$ yra sukaupti duomenys apie visas žinomas publikacijas archeologijos tematika (iskaitant klausimus, susijusius su karybos istorijos tyrimais),

\footnotetext{
${ }^{26}$ Lietuvos pilys. V., 1971.

${ }^{27}$ Lietuvos gynybiniai įtvirtinimai. / Sud. A. Kuncevičius. V., 2001.

${ }^{28}$ Lietuvos pilių archeologija. / Sud. J. Genys, V. Žulkus. Klaipėda, 2001.

${ }^{29}$ Jankauskas R. Lietuvos gyventojų antropologija: nuo seniausių laikų iki XIII a. // Istorija. T. 50. V., 2001, p. 38-45; Jankauskas R., Zakaras A. Traces of skull lesion caused by sharp instrument on the 13 th C. ad // Medicina Legalis Baltica, 1993. N. 3-4, p. 113-114.

${ }^{30}$ Lietuvos archeologijos bibliografija 1782-1998 / Sud. A.Tautavičius V., 2000.
} 
pasirodžiusiais 1782-1998 m. Pagrindiniai nuo 1999 m. pasirodę darbai paminèti šiame straipsnyje. Be to, daugelyje publikacijų, skirtų archeologiniu tyrimu duomenu apžvalgai, galima aptikti informacijos, vienaip ar kitaip susijusios su žmonių karinès veiklos praeityje pažinimu. Kasmet tiriami laidojimo paminklai, gyvenvietės, piliakalniai, pilys, randama ginklų, kitų karybos pėdsakų. Bendrieji tyrinejjimų duomenys skelbiami kas dvejus metus leidžiamame tęstiniame leidinyje „Archeologiniai tyrinéjimai Lietuvoje“.

Taigi apibendrinant galima pasakyti, kad Lietuvos archeologai yra sukaupę labai daug mokslinių tyrinéjimų duomenų, vertingu Lietuvos karybos istorijai pažinti, tačiau stokojama specializuotų studijų, apibendrinamojo pobūdžio darbų. Karybos istorijos tyrimų prioritetas archeologijos srityje artimiausiu metu turètų tekti ne tiek tolesniam su karyba susijusių archeologijos paminklu tyrimui, kiek jau sukauptų tyrinejjimų duomenų apibendrinimui ir įvedimui i Lietuvos bei tarptautinę karybos istorijos mokslo apyvartą.

İteikta 2002-11-25 


\section{RÉSUMÉ}

\section{Le rôle de la science archéologique dans les études sur l'histoire militaire lituanienne}

\section{Manvydas Vitkūnas \\ Université de Vilnius}

Les principales directions présentes et possibles des recherches archéologiques, liées à la connaissance de l'histoire de l'art de la guerre lituanien, sont parcourues dans cet article.

Il est possible de classer les traces d'activité militaire humaine prouvées par l'archéologie en plusieurs groupes principaux, dont deux plus manifestes: l'armement et ses éléments ainsi que les fortifications et leurs vestiges. Les stèles funéraires et les traces des anciens lieux habités, qui subissaient les assauts militaires, sont aussi importants pour les études sur l'histoire de l'art de la guerre. Les études sur les métiers permettent de connaītre l'évolution des technologies utilisées pour les besoins militaires. Les premiers archéologues et historiens lituaniens s'intéressaient déjà aux traces de l'art de la guerre d'autrefois, mais des publications spécialisées ne sont parues que pendant l'entre-deux-guerres.

La période allant du paléolithique à la fin de l'Age de fer précoce est la moins étudiée du point de vue de l'histoire de l'art de la guerre. De nombreux matériaux ont été rassemblés sur les outils de chasse et l'armement de cette époque, beaucoup de place est laissé aux armes dans les travaux de nature générale, et pour parler de l'Age de bronze et de fer précoce - et du début de la construction de fortifications, il n'existe pas de travaux spécialisés jusqu'à aujourd'hui et les articles isolés sont assez modestes. La période du Ier millénaire aprčs la naissance du Christ et le début du IIe millénaire sont beaucoup mieux étudiés du point de vue de l'histoire de l'art de la guerre. La typologie et la chronologie de l'armement de cette période sont le mieux analysées.

Les fortifications défensives, surtout appartenant à l'époque médiévale et moderne, sont assez bien étudiées. Il s'agit de recherches sur les tertres de chāteaux, sur lesquels se trouvaient des abris 
en bois, ainsi que les châteaux en maēonnerie et les fortifications défensives. Il manque des publications généralistes sur les études des chāteaux en maēonnerie. La fortification médiévale est bien étudiée mais l'armement mal.

L'anthropologie, et tout d'abord la paléopathologie, apporte une information sur les conflits militaires du passé. Les scientifiques de la faculté de médecine de l'Université de Vilnius travaillent dans ce domaine.

Les archéologues lituaniens ont rassemblé de très nombreuses données sur les études scientifiques précieuses pour la connaissance de l'histoire de l'art de la guerre, mais il n'y a pas assez d'études spécialisées, ni de travaux généralistes. La priorité des recherches sur l'histoire de l'art de la guerre dans le domaine archéologique devrait źtre, pour les prochaines années, la généralisation des données des études et leur introduction dans la science historique lituanienne et internationale sur l'art de la guerre. 